\title{
THE RHETORIC OF VIOLENCE, RELIGION, AND PURITY IN INDIA'S COW PROTECTION MOVEMENT
}

\author{
Juli L. Gittinger \\ Georgia College
}

\begin{abstract}
In India there has been a recent increase in violence and intolerance towards people who eat beef. While India has a fairly wide Cow Protection Act that bars the slaughter of female cows and calves, many areas have permitted slaughter of bulls and bullocks for centuries. Hindu religion has no doctrinal proscriptions against the consumption of beef in particular, although it has borrowed heavily from Jainism in the last century, arguing that the concept of ahimsa (nonviolence) forbids such slaughter and consumption of beef. Violence is exacted upon those who would dare eat beef_-notably Muslims and lower castes_-further politicizing the issue. This paper explores the various claims and legitimations of violence regarding the tradition of abstaining from beef. These include arguments of religious purity, racial biases, caste, and cultural arguments which have been put forth in defense of or in condemnation of beef-eaters. I argue that, in the case of such regulations of "authentic" Hindu traditions (like the sanctity of the cow), purity concerns are directly tied to Hindu nationalist ideologies.
\end{abstract}

Keywords: Hinduism, cow protection, caste, nationalism, purity, nonviolence

n 2014, Narendra Modi became the Prime Minister of India-the first political candidate to displace the Nehru-Gandhi dynasty, thereby replacing the Indian National Congress party's domination in the Parliament with the more right-wing, conservative BJP (Bharatiya Janata Party). Since then, the rise of Hindu nationalist rhetoric has been visible both in media and in policy, as conservative ideals of "authentic" Hinduism once again enter the public sphere. One of the more provocative issues to arise is the subject of cow slaughter. Despite India's pluralism and secular landscape, a pervasive Hindu fundamentalism has been present among Hindu nationalist organizations like the BJP, which now claims authority to delineate the authentic or 
pure traditions from the Westernized or corrupted traditions. Cow slaughter has become a point around which such ideologies rally.

The agitation to ban cow slaughter and beef consumption has recently manifested in violence. In October 2015 a fifty-two-year-old Muslim man was dragged from his home and beaten to death for (allegedly) eating beef. The victim, Mohammad Akhlaq, was home with his family when a mob showed up at his home and attacked him and his son with bricks. The rumor that he had beef in his home originated from a local temple, who routinely admonished the practice of consuming impure substances. According to police reports, only mutton (goat meat) was found on the property, making the tragedy even more unfortunate.

In this essay I will examine the historical and doctrinal understandings of the "sacred cow," particularly in the context of caste and non-violence. I conclude with an examination of cow protection rhetoric as it has manifested among Hindu nationalist groups. Such movements have drawn from the religious ideals of caste purity and non-violence but, in reality, are couched in purity of a Hindu nation which excludes anyone who falls outside a rather upper-caste Hindutva ideal. This paper will explore the various claims made and legitimation of violence regarding the tradition of abstaining from beef. These include religious, racial, caste-based, and cultural arguments, which have been put forth in defense for or in persecution of beef-eaters. Purity, as I will argue, plays a role not in relation to non-violence or meat consumption, but rather an ideology of a "pure and authentic" ideal of Hinduism as promoted by nationalist organizations.

\section{THE ORIGINS OF THE "SACRED COW"}

The representation of cows and bulls in India can be seen as early as the Harappa period (2500-1750 BCE), when animals were depicted on stone seals. The horned bull appears on several of these archeological artifacts, often with a seated figure who is speculated to be a prototype of Shiva. The placement of these bovine figures in iconography, with what is often interpreted as ritual items, suggest that these animals had significance-although to what extent we do not know. The Indus script of the Harappa civilization is largely a body of non-linguistic symbols, ${ }^{1}$ and thus archeologists and historians have to rely upon best guesses for interpreting this ancient culture and its traditions.

The Vedic civilization came to flourish as the Harappan civilization declined, around 1750-500 BCE. This period is characterized by Aryan migration, an influx of nomadic tribes from Central Asia. They brought with

${ }^{1}$ See Lawler 2004. 
them rituals and mythologies that became characteristic of early Hinduism, and it was during this period that Vedic literature was written. Vedic rituals were dominated by fire sacrifices during which food offerings were placed in the ritual fire. These included sacrificial animals, as well as non-meat products such as honey, milk, and ghee. The gods of the Vedic period showed no abstention from meat: Indra liked bulls, Agni liked horses and cows, and the killing of an animal was a frequent part of a yajna ritual. "The slaughter of animals formed an important component of the cult of the dead in Vedic texts." 2 Cow or ox offerings were frequently given to the dead as part of funerary rituals.

Animal worship was not prevalent in the Vedas, although many deities had an animal companion. Perhaps most notably is Shiva's companion Nandi, a Zebu bull, which was also an animal frequently represented on the Harappan seals. In Puranic literature, animal companions often have anthropomorphic qualities and are viewed sacred, even though they are not directly worshipped. Xenia Zeiler writes about Nandi's unique role in contemporary Hindu practice:

Most frequently, he is shown as a bull, standing or lying down. In a lying position his left leg is usually bent, and at times this iconographic detail is included in popular ritual practice. At several huge Nandi statues in India women wishing to have a child crawl through the hole of the bull's bent leg, which most likely point to notions of fertility attributed to the bull Nandi in popular belief. ${ }^{3}$

While not outright worshipped, it is clear that Nandi, and other animal companions to the deities, have a sacred status.

This does not, however, account for a reluctance to kill an everyday cow or consume its meat. In fact, D. N. Jha argues that, "self-styled custodians of non-existent 'monolithic' Hinduism assert that eating of beef was first introduced in India by the followers of Islam who came from outside and are foreigners in this country, little realizing that their Vedic ancestors were also foreigners who ate the flesh of the cow and various other animals." 4 So how did Vedic or brahminic Hinduism come to be understood as purified of meat consumption?

Zeiler speculates that ahimsa may play a role in this particular Hindu ideology. While the concept of ahimsa was largely absent from the Vedic period, the principle of non-violence or "do no harm" does, however, grow as an ethical concept in the Upanisads. The Chandogya Upanisad (seventh

${ }^{2}$ Jha $2002,139$.

${ }^{3}$ Zeiler 2013, 134.

4Jha 2002, 20. 
century BCE) is thought to have the earliest use of ahimsa as a virtue (CU 3.17.4) and as a code of conduct:

All this Brahma told to Prajapati; Prajapati to Manu; and Manu to his children.

From the teacher's house-where he learned the Veda in the prescribed manner during his free time after his daily tasks for the teacher-he returns, and then, in his own house, he does his daily vedic recitation in a clean place, rears virtuous children, draws in all his sense organs into himself, and refrains from killing any creature except for a worthy person-someone who lives this way all his life attains the world of a brahman, and he does not return again. ${ }^{5}$

The ethical principle of non-violence was not a dominant theme in Indian classical literature, however. Hindu epics such as the Mahabharata were largely about warring clans and family conflicts, and violence was seen as just and necessary in the context of dharma and the caste role of a kshatriya (warrior/nobleman). The Bhagavad Gita, arguably a treatise on Just War, is a teaching by Krishna given to the despondent Arjuna as to why war (and the inevitable slaughter of his cousins) is dharmically sound. Gandhi, on the other hand, interpreted the Bhagavad Gita metaphorically and argues that the text advocates for ahimsa and eschews violence.

The tradition of ahimsa is better connected with Jainism, a religion which was shaped by Mahavira (fifth century BCE, about same time as the Buddha). Both Mahavira and the Buddha formed traditions in response to Vedic cultures of formalized rituals, animal sacrifice, and brahminic dominance. For the Buddha, he chose a "middle path," between asceticism and materialism, but for Mahavira the pendulum swung the extreme opposite of Vedism. Jainism valorizes ahimsa above all other virtues, taking non-violence to extremes, rejecting Hindu values like artha (success) and kama (pleasure) in favor of brutal asceticism. While some Buddhists do eat meat (indeed, Buddha's last meal was reportedly meat), Jains refrain from eating any animal flesh.

Gandhi was influenced by the Jains in his native province of Gujarat; Jainism's ideologies most certainly informed his ideas of brahamacarya (celibacy) and ahimsa (non-violence). Gandhi's position on the sacralization of the cow moved into more religious language later, as nationalist movements began to assert themselves in the political landscape, but his initial position regarded cow protection as fairly pragmatic:

Mother cow is in many ways better than the mother who gave us birth. Our mother gives us milk for a couple of years and then expects us to serve her when we grow up. Mother cow expects nothing from us but grass and grain. Our mother often falls ill and expects service from us. Mother cow rarely

${ }^{5}$ Chandogya Upanisad 8.15. Emphasis mine. 
falls ill. Our mother when she dies means expenses of burial or cremation. Mother cow is as useful dead as when alive. ${ }^{6}$

In this passage from Gandhi, it is clear that the cow is important because she fulfills many resource needs - a practical and non-religious argument, which is obfuscated in later years by misconceptions that the cow was deemed sacred in the Vedas. He aligns cow protection with Hinduism in later writings:

The central fact of Hinduism however is cow-protection. Cow protection to me is one of the most wonderful phenomena in human evolution. It takes the human being beyond his species. The cow to me means the entire sub-human world. Man through the cow is enjoined to realize his identity with all that lives. Why the cow was selected for apotheosis is obvious to me. The cow was in India the best companion. She was the giver of plenty. Not only did she give milk, but she also made agriculture possible. The cow is a poem of pity. One reads pity in the gentle animal. She is a mother to millions of Indian mankind. Protection of the cow means protection of the whole dumb creation of God. The ancient seer, whoever he was, began with the cow. The appeal of the lower order of creation is all the more forcible because it is speechless. Cow protection is the gift of Hinduism to the world. And Hinduism will live so long as there are Hindus to protect the cow. ${ }^{7}$

Gandhi goes on to list the ways in which a Hindu should protect cows, stating that it is incumbent as a religious duty. As a result, cow veneration "has been converted into a symbol of communal identity of the Hindus and obscurantist and fundamentalist forces obdurately refuse to appreciate that the cow was not always all that sacred in the Vedic and subsequent Brahmanical and non-Bramanical traditions." Gandhi is quick, however, to emphasize the role of non-violence in this protection: "The reader will observe that behind the foregoing requirements lies one thing and that is Ahimsa." ${ }^{, 9}$ While Gandhi is frequently invoked on the subject of cow protection, ahimsa is not central to the mission of contemporary cow protection organizations, as I will show.

Other texts also discuss the cow; in Manusmriti (Laws of Manu), the cow is mentioned many times throughout the text. It is given special reverence (e.g., one should circumambulate them to the right when encountered, 4.49) and its products (milk, ghee, dung, urine) are enumerated as purifying for rituals. Killing a cow is a "minor crime" for which the person "should drink barley-broth for a month; he should have his head shaved and live in the cowpen, wrapped in (the cow's) hide" (11.109). It must be noted, however,

${ }^{6}$ Gandhi 1940.

${ }^{7}$ Gandhi 2009, 123.

${ }^{8}$ Jha 2002, 20.

${ }^{9}$ Gandhi 2009, 125. 
that Manu's collection of rules and laws are for the twice-born castes - that is, they apply to the top three (brahmin, kshatriya, vaishya) tiers of Hindu society and not to the lowborn shudra caste, and certainly not to the Dalits who are often not even classified as Hindu, falling outside the varna system entirely.

The question of cow protection, therefore, initially seems to be bound up in questions of both caste purity and ethics of non-violence. Although casteism and violence remain central issues today, the modern cow protection movements reveal a growing concern with a purity of Hindu tradition in the context of nationalism.

Early Hindu nationalist movements did not embrace ideals of ahimsa. In fact, the emasculation from colonial occupation and the valorization of "martial races" like the Sikhs and Rajputs created a very masculinized ideal of a Hindu nation that saw non-violence as weakness. The influential and oft-cited treatise for Hindu nationalist ideology is Hindutva: Who is a Hindu? Written by V. D. Savarkar in 1923, it strongly railed against the principle of ahimsa. In fact, he saw Buddhism as an important and respected tradition that was born in India—and thus part of the "Hindu" family—but was grateful that ultimately its ethos was rejected.

Nobly did she [India] try to kill killing by getting killed — and at last found out that palm leaves at times are too fragile for steel! As long as the whole world was red in tooth and claw and the national and racial distinction so strong as to make men brutal, so long as India had to live at all a life whether spiritual or political according to the right of her soul, she must not lose the strength born of national and racial cohesion. ${ }^{10}$

To "change her sword for a rosary" may be noble in intention, but ultimately could not work for the protection of the nation. To adopt a religion dogma of non-violence was to be victim to the world's aggressors:

What was the use of a universal faith that instead of soothing the ferociousness and brutal egoism of other nations only excited their lust by leaving India defenceless and unsuspecting? No; the only safe-guards in future were valour and strength that could be born out of a national self-consciousness. She had poured her life's blood for sophistry that tried to prove otherwise! ${ }^{11}$

Therefore, in relation to Hindu nationalism, the invocation of non-violence (in the context of cow protection) is invalid. Hinduism is not inherently nonviolent, and while its texts have characterized ahimsa intermittently as a noble aspiration, they more consistently emphasized the duties of caste (of the warrior in particular). India's history, as retold through both literature and propaganda,

\footnotetext{
${ }^{10}$ Savarkar 2005 [1923], 23.

${ }^{11}$ Savarkar 2005 [1923], 25.
} 
is one that takes a defensive posture against invaders and foreigners. Even Mother India, often iconographically represented as a Durga figure, is both beautiful and virtuous - and thus must be protected at all costs—yet, as Durga, she is also a fierce warrior.

Cow protection would therefore be best analyzed not in relation to ahimsa, but rather as a sacralization of a particular animal as symbol. As a symbol, we must then analyze what it (and its slaughter or consumption) represents in the popular Hindu imagination.

\section{PURITY OF CASTE OR PURITY OF NATION?}

Hinduism is often associated with vegetarianism, which in turn points to two religious ideals: ahimsa, which we have already discussed, and purity. Purity, in this sense, is related to caste. While the caste system in India has been argued by scholars to have been crystallized into its present form during British colonial periods-largely due to the project of categorizing, mapping, and naming their subjects ${ }^{12}$-its roots are from the idea of varna (color), which is only referenced to once in the Vedas:

When they divided the Man, into how many parts did they apportion him?

What do they call his mouth, his two arms and thighs and feet? His mouth became the Brahmin; his arms were made into the Warrior, his thighs the People, and from his feet the Servants were born. ${ }^{13}$

The primordial man Purusha is divided here to bring forth humankind, the purest beings (brahmins) from the head, the least pure from the feet (shudra), with warriors (kshatriya) and tradesmen (vaishya) in between. This idea of purity as quite literally top-down is reiterated by occupations: Brahmins or priests have the "cleanest" jobs, whereas Shudra or laborers having "dirty" jobs. Outside and below the varna/caste stratification are the Dalits (formerly referred to as "untouchables") who do the truly unclean work: handling of dead animals, leather tanning, sewage cleaning, cremation, etc. Thus the hierarchal structure is not only stratified by social class and occupation, but often by physical cleanliness in a very real way.

While it is frequently argued that the varna system is legitimately, authentically Hindu-deriving from sacred texts and thus intrinsic to Hindu tradition (and indeed this is the position of Hindu nationalists and upper-castes) - the reality is quite different. As I noted earlier, the compulsion to categorize, map, and name was part of the colonial project and has been argued to have greatly

\footnotetext{
${ }^{12}$ See Dirks 2001; Rao 2009.

${ }^{13}$ Rig Veda 10.90.11-12.
} 
contributed to the rigidity of the so-called "caste system" as it exists today. ${ }^{14}$ The introduction of a census had the greatest impact because it encouraged caste groups to organize themselves and even form associations in order to be properly represented. The census thereby created pressure for each caste group to improve their rank in order to eventually claim advantages from the colonial administration. Through these imperial processes, the social divisions of various labor classes became more rigid, and the upper castes more elite. "[U]ntil the British colonization of India, for the people of the subcontinent, the formal distinctions of caste had limited importance for their individual and corporate lifestyles." ${ }^{15}$ Furthermore, the British initially relied heavily upon Hindu brahmins and pandits for introductory knowledge of religious and cultural traditions; thus it is no surprise that the texts put forth as most "orthodox" or authentic were those that favored brahminical hierarchy. Manusmrti (Laws of Manu) was one of the first such Sanskrit texts translated by Sir William Jones in 1794. While scholars have disputed the likelihood that this legal text was used in medieval Hindu society, it nonetheless was held up as a central dogmatic text that came to inform early British policies regarding their Hindu subjects.

Manu was one of several Dharmashastras or legal texts in existence in India, although Hindu traditions draw from a wide variety of texts when it comes to belief, behavior, social relationships, and religious/cultural traditions including: the Vedas, Upanishads, the Bhagavad Gita, the great epics, and many other pieces of literature. For the colonials, the lack of a singular doctrinal text-like the Christian Bible or Muslim Qur'an - made Hinduism a more complicated tradition with which to work. Ignorance of Sanskrit and other regional languages forced a reliance upon the literate, scholarly brahmins who in many ways shaped what came to be understood as "authentic" Hinduism, and caste was a part of that understanding that the British codified.

This is not to say the British invented caste. Nicholas Dirks argues that under the British, caste "became a single term capable of expressing, organizing, and above all 'systematizing' India's diverse forms of social identity, community and organization," thereby producing conditions that made caste a central feature of Indian society. ${ }^{16} \mathrm{He}$ goes on to note:

British colonialism played a critical role in both the identification and the production of Indian "tradition." Current debates about modernity and tradition fail to appreciate the extent to which the congeries of beliefs, customs,

\footnotetext{
${ }^{14}$ See Dirks 2001; Rao 2009.

${ }^{15}$ Jayaram 2011, 86.

${ }^{16}$ Dirks 2001, 5.
} 
practices, and convictions that have been designated as traditional are in fact the complicated byproduct of colonial history. ${ }^{17}$

The role of Orientalism here is not to be underestimated. Edward Said's invaluable theory of Orientalism discusses how colonial power and knowledge reify stereotypes about cultures, producing narratives that normalized colonial power to further reproduce and delineate frameworks of knowledge. The pointing back to the Vedas' description of varna as an idealized social hierarchy, in which all members of society work together for the greater benefit of all, is an Orientalist nostalgia of the worst kind.

The Dalits or outcastes are outside the varna system entirely; it is here where the caste system is the ugliest. Discrimination is pervasive against Dalit communities and individuals, even when they have converted to Christianity, Islam, or Buddhism. In this way, the status of the Dalits is not a Hindu designation, and indeed Hindu nationalist organizations often target Dalits for recruitment, hoping to bring them into the "Hindu fold." Yet their social status is entirely informed by understandings of Hinduism-notably karma, dharma, and rebirth.

The "practice of untouchability" has been legislated against, making it illegal to bar Dalits from temples or to deny them access to basic resources (like water), yet discriminatory practices remain visible and pervasive. While the constitution of India guarantees equal rights, ${ }^{18}$ laws like the Untouchability Offences Act (1955) and the Prevention of Atrocities Against Scheduled Castes and Scheduled Tribes Act (1989) were enacted to punish those who would continue to discriminate against Dalits, and to refine the definition of such criminal acts to include public humiliation, coercion, and sexual violence. ${ }^{19}$ "Amended laws eventually produced a definition of untouchability: a list of acts, public manifestations of the practice, which encompassed ritual and symbolic humiliation as well as physical violence." ${ }^{20}$ This has done little to prevent violence, however, and little to emphasize Dalit personhood.

By defining Dalits as injured subjects who are susceptible to continued harm, protective measures produced more proximate relation between Dalits and the state and impelled the development of regulatory structures and disciplinary mechanisms to protect them. The effect of these measures, however, was both ironic and unanticipated, for the legislation of caste crime heightened the

${ }^{17}$ Dirks 2001, 9.

${ }^{18}$ Article 17 of the Constitution of India states: “'Untouchability' is abolished and its practice in any form is forbidden. The enforcement of any disability rising out of 'Untouchability' shall be an offence punishable in accordance with law.'

${ }^{19}$ Rao $2009,175$.

${ }^{20}$ Rao 2009, 175. 
salience of caste conflict by drawing attention to the presence of anti-Dalit violence as a fact of everyday life. ${ }^{21}$

Christophe Jaffrelot has argued that nationalist ideologies reflect ideas of purification and caste models through the practice of shuddhi, the "purification" or "reconversion" of Dalits who have left Hinduism for Islam or Christianity (although one could easily assert that as Dalits, they are already outside Hinduism-one of the reasons they are targets for proselytization and conversion). Jaffrelot suggests that conversion out of Hinduism is seen as "denationalization," and for this reason purity of tradition and of the nation become synonymous. ${ }^{22}$

This is also evident in Savarkar's writings, which promote a kind of ethno-nationalism that is couched in both ethnic purity (tracing bloodline to the "noble Aryans" who settled in the Indus River Valley) and in the idea of the nation as sacred. Hindutva or "Hinduness" thus was defined by Savarkar as jati (same bloodline), rashtra (same nation), and sanskirti (same civilization/culture). These are explained in great detail, and reiterated throughout the text. A summary can be found towards the conclusion:

A Hindu then is he who feels attachment to the land that extends from Sindhu to Sindh as the land of his forefathers-as his Fatherland; who inherits the blood of the great race whose first and discernible source could be traced from the Himalayan altitudes of the Vedic Saptasindhus and which assimilating all that was incorporated and ennobling all that was assimilated has grown into and come to be known as the Hindu people. ... That is why Christian and Mohammedan communities, who, were but very recently Hindus and in a majority of cases had been at least in their first generation most unwilling denizens of their new fold, claim though they might have a common Fatherland, and an almost pure Hindu blood and parentage with us, cannot be recognized as Hindus. ${ }^{23}$

Violence is legitimated against those who pose a threat to the ideal of the "nation," and that includes Muslims (who are foreigners anyway) and Dalits who, by existing outside the varna system, may be seen as potentially disloyal.

Swami Dayananda forged a Hindu revivalism that included reconversion of Dalits, who had become Christian or Muslim in effort to escape caste stigmatization, and an emphasis on purity. This included valorization of brahmacarya (celibacy) and purification of the Hindu nation through casteism which saw a crucial balance of occupational roles for society. The controversy

\footnotetext{
${ }^{21}$ Rao 2009, 177.

${ }^{22}$ Jaffrelot 2016.

${ }^{23}$ Savarkar 2005 [1923], 100.
} 
thus focused on two points: cow protection as sacred Hindu duty, and defense against the perceived threat of Muslims (cow eaters) in India.

As a symbol, therefore, the cow refers back to an idealized Hindu culture/ nation, one that stretches back as a contiguous line to the ancient Harappa civilization, and prioritizes the Vedas as ultimate religious revelations and varna as a divinely ordained system of social organization. The cow's relationship with deities like Shiva and the abstention of meat eating by the upper caste (Brahmins) both reiterate ideas of sacrality and purity. Lastly, referring to the cow as "mother" (as Gandhi does) evokes the same imagery as the term "Mother India" - symbolic purity and virtue that must be protected at all costs against those who threaten the Hindu Nation.

\section{VIOLENCE IN THE NAME OF “COW PROTECTION”}

September 2015: A 50-year old man in Uttar Pradesh is lynched by a mob for rumors that his family had been consuming and storing beef at home.

February 2016: In Agra, VHP official Arun Mahour is shot by an angry group of Muslims who had previously been targeted for eating beef. Hindus attempt to retaliate against the Muslim quarter.

July 2016: Four Dalit men in Gujarat are tied up and brutally beaten publicly over alleged cow killing. They were apparently removing the skin off a carcass of an already-dead cow, as they worked in a tannery.

July 2016: In protest for the inhumane treatment of the aforementioned Dalits, seven other young Dalit men attempt suicide to publicly protest the beatings.

July 2016: A video recording of the four men getting beaten goes viral and causes riots in Gujarat.

September 2016: Biryani sellers in Muslim-dominated Haryana state (governed by the BJP) are accused of having beef in their dish and lose their businesses as a consequence of the unfounded accusation.

September 2016: Over forty Muslim homes are ransacked and vandalized by police and cow protection mobs in Alwar. Police claim they recovered 36 cow carcasses and 6 cows, but locals say the mob ransacked their homes and slaughtered their animals.

According to the National Sample Survey Office (NSSO), which is the largest organization in India conducting regular socio-economic surveys, over 80 million Indians (1 out of every 13) eat beef or buffalo meat. Most of these Indians are Muslim, but as many as 12 million Hindus also eat beef. Beef is often cheaper than chicken or fish and is often a staple for poor Muslim, Dalit, and tribal communities. 
Across the majority of states in India, it is illegal to slaughter a female cow or calf - an argument that is practical when considering the dairy and dung products that are produced. The slaughter of a bull, however, has enjoyed various states of legality depending on the region and the time period. In most parts of India, the slaughter of bulls and bullocks are permitted. The banning of all bovine slaughter and sales are found predominantly in the north-western parts of India. A few areas, such as Kerala, Assam, and West Bengal, have no restrictions. It is also worth noting that India is the fifth largest beef producer worldwide, with nearly half of the beef exported. To date, India is the largest producer of milk in the world, dairy products being an important staple of the Indian diet. Yogurt, paneer (cheese), and condensed milk sweets are widely consumed. Ghee (clarified butter) and milk are sacred libations often used in puja rituals.

Districts like Rajkot, Gujarat, where the leather working quarters can be found, are particularly vulnerable. Dalits who work with dead carcasses are among the lowest of the low, considered impure both symbolically (in having contact with a dead body) and physically (leather tanning is dirty work). Families which have been part of the leather industry for generations now fear for their livelihood in a system that doesn't easily allow occupational mobility. Furthermore, because stray cattle wander through both urban and rural areas, when one of them dies, it must be removed. Municipal authorities often contact Dalit leatherworkers to take the body away. One worker comments: "When we carry dead animals, they inquire where they come from. When we carry hides or bones, we face the same thing." ${ }^{24}$ The word "they" refers to vigilantes from various nationalist groups who police cow slaughter in their areas.

It is not just Dalit leatherworkers who are targeted. Butchers and sellers of beef, as well as those who consume it, are also threatened. Muslims in particular have no dietary laws regarding the abstention of beef (only that it must be halal, a method of slaughtering similar to Jewish kosher laws).

It is a bit ironic that Hindu nationalist organizations have taken up such anti-beef rhetoric. There was a time when the absence of animal protein (other than yogurt and cheese) in the Indian diet was a concern for Hindu nationalists. Vivekananda famously remarked that India needed "beef, biceps, and the Bhagavad Gita." This ideology can be found in the Osmania University beef festival, held for several years now. The festival offers a wide range of beef delicacies and a bold helping of ideology, which asserts that Hindu Brahmins conspire to impede on the physical and intellectual growth of the Indian masses by encouraging the consumption of low proteins and vegetarian

${ }^{24}$ Prabhu 2016. 
diets. It is argued that while Brahmins can supplement their diet with milk, yoghurt, and ghee, these are not always affordable for India's low classes and tribes. Comparing themselves to rich meat-consumption countries in Europe and Americas, Osmania "beeferians" believe that vegetarianism and prohibition of cow slaughter have been co-opted by Hindutva organizations to protect the status quo of the upper castes. ${ }^{25}$

Despite this argument - which would feed into the more masculine narrative of nationalism - the BJP has launched aggressive campaigns against cow slaughter and beef consumption, only stoking the fires of communal division. "The cow is not just an animal. We have emotional and religious attachment to it and we want to make it the center of our economic activity," a senior RSS leader states. ${ }^{26}$ Despite the fact that cow slaughter is already prohibited in most states, there is a growing hysteria that cows are under threat. As a result, new nationalist organizations have cropped up as vigilante protectors of the purity of Hinduism and national ideology.

Bharatiya Gau Raksha Dal (henceforth the Dal) was founded in 2012 by Pawan Pandit. The members or Gau Rakshaks are charged with protecting cow rights in areas such as Punjab, Haryana, UP, Bihar, Orissa, Madhya Pradesh and Rajasthan-most of which are BJP-led states. On the Dal website, the image of Krishna as Gopal or cowherd is featured, as well as Gandhi's quote, "The central fact of Hinduism is cow protection." ${ }^{27}$ A list of "lives we have saved" is provided by region: 2,000 in Delhi, 4,000 in Uttar Pradesh, 3,000 in Maharashtra, and 2,000 in Bihar. One presumes they are talking about cow lives, since the life of a Dalit or Muslim seems forfeit.

Unlike other groups who blame Muslims for introducing cow slaughter, the Dal blames the British and provides graphic stories of how cows were presumably slaughtered. "As a part of the Master plan to destabilize the India, cow slaughter was initiated. The first slaughterhouse in India was started in 1760, with a capacity to kill 30,000 (Thirty thousand only) per day, at least one crore cows were eliminated in a year's time." ${ }^{28}$ But, lest the Muslims get off in this tale, we have this reminder: "As per a report, money derived from selling bones of cows (approximately Rs. 2000 crore) is used solely for the purpose of jihad. Jihadis don't use this money for themselves. Every year, a

25"Ninety percent of students on OU campus are Dalit-Bahujan, most whom are beef eaters. Section 29 (A) of the constitution ensures that 'any section of the citizens residing in the territory of India having a distinct language, script or culture of its own shall have the right to conserve the same,"' said B. Sudarshan of Osmania University. See Henry 2015.

${ }^{26}$ Nair 2015.

${ }^{27}$ Bharatiya Gau Raksha Dal 2014

${ }^{28}$ Bharatiya Gau Raksha Dal 2016 
total of approximately one crore cows are slaughtered and the money earned from it is used for jihad by terrorists." ${ }^{29}$ Lastly, they state that the slaughter of cows is akin to the slaughtering of Hindus and of Mother India. So again, it finally returns back to the ideological model of a Hindu nation.

Arjun Appadurai's concept of "predatory identities" is useful here. Predatory identities emerge out of two groups who have long histories of close contact and some degree of mixing, and take shape when one group (in this case, Hindus) understands itself as a threatened majority. "This kind of mobilization is the key step in turning a benign social identity into a predatory identity." 30 These identities emerge in what Appadurai calls "the anxiety of incompleteness"- that is, when the larger group fears the small numbers of the minority group because it frustrates the larger group's ideal of national wholeness and purity.

He provides the example of Germanness, which was the predatory identity of the Nazis in relation to the Jews, who the Nazis feared as a disruption of the wholeness of that national identity. We can draw similar parallels to contemporary discourse in the U.S. regarding immigrants and minority religions. India, which has had its genocidal moments (pogroms of Gujarat in 2002, for example), largely relies on the technique Hannah Arendt named "the banality of evil." ${ }^{31}$ In this model, violence is systematized and bureaucratized. It is legitimized, in this instance, as religious, by political parties who have established a particular rhetoric of nationhood and religious/cultural purity. That religious/cultural narrative is tied to an ideal of Hindu India as an unbroken, contiguous line stretching back to the Harappa civilization four thousand years ago. Muslims, as told by history, were an intrusion. They invaded, colonized, ravaged, and assimilated to some degree, but never truly embraced authentic Hindutva or Hindu-ness.

India was formed against a competing identity: Pakistani. Nationalism easily found a "we-ness" (to use Appadurai's word) that perhaps set Hindus against Muslims from day one. While Nehru's idea of India was secular and inclusive, the rise of groups like the BJP have demonstrated a movement away from that vision of India, and more towards a defensive, protective posturing. As Appadurai observes:

[T] he world's largest democracy, born with a constitution that pays remarkable attention to religious inclusion, secular tolerance for religious difference, and a general concern with protecting the 'weaker sections' of society, could, within forty years of its birth, have turned into an aggressively Hinduized

\footnotetext{
${ }^{29}$ Bharatiya Gau Raksha Dal 2016

${ }^{30}$ Appadurai 2006, 51.

${ }^{31}$ Arendt 1963.
} 
polity, which repeatedly and systematically sought to identify India with Hindus and patriotism with Hindutva (Hindu-ness). ${ }^{32}$

Indian Muslims are seen as instruments of global Islamic movements and not (ultimately) loyal to India; Dalits are seen as unstable categories that do not fall into Hinduism's varna system and therefore pose a problem of potential defection to other religions (and therefore nations). Recall that Jaffrelot suggested that conversion out of Hinduism is seen as "denationalization." Outcastes or Dalits also present a threat to the wholeness of the Hindu nation. There was the idealistic view, like that of Gandhi, that hereditary occupations fulfilled a natural social order that was connected to the doctrine of rebirth, dharma, and karma. And then there was the view that by creating a group marginalized and categorized apart from upper caste Hinduism, the group could effectively mobilize against the status quo. Politically, Dalits include a number of "backwards groups" which include Muslims, Christians, tribals, and outcaste Hindus - the last thing an organization like the BJP would want is a way for these disparate groups to unite under one vote bloc.

Prime Minister Narendra Modi has spoken out against the vigilante cow protectors, calling them "anti-social" "troublemakers" that have "nothing to do with cows." ${ }^{33}$ But this is only a political move to distance himself from the Gau Rakshaks. The rhetoric of authenticity and Hindu revivalism has dominated Modi's politics since he turned his eye to the role of Prime Minister. And when Modi wasn't explicit, the BJP was. For years the group has promoted its summary of "cultural heritage" on both websites and manifestos, and the subject of cow protection most recently making an appearance on the 2014 election manifesto.

Cow and its Progeny: In view of the contribution of cow and its progeny to agriculture, socio-economic and cultural life of our country, the Department of Animal Husbandry will be suitably strengthened and empowered for the protection and promotion of cow and its progeny. ${ }^{34}$

This is more strongly worded in the 1998 manifesto, which is still available on the BJP website:

THE BJP regretfully observes that, despite Article 48 of the Constitution, millions of cows and cow progeny are slaughtered every year, most of them for export, thereby causing irreparable harm to agriculture and villages. Keeping in view Article 48, the BJP will:

\footnotetext{
${ }^{32}$ Appadurai 2006, 67-68.

${ }^{33}$ Gowen 2016.

${ }^{34}$ Bharatiya Janata Party 2014
} 
1. Impose a total ban on the slaughter of cows and cow-progeny, including bulls and bullocks and prohibit all trade, including export (state as well as private) in beef.

2. Create a policy that will result in improved cattle breeding.

3. Exempt the income of Goshalas and Pinjrapoles from tax.

The BJP recognizes the fact that from times immemorial, cow-protection has remained of the basics of Indian culture and Indian agriculture and it is on the patient back of the cow and its progeny that the entire structure of Indian agriculture rests. Over seven crore animals are employed in farming operations in Indian villages, more than 80 per cent of the rural transport needs are met by the bullock cart. Our livestock is also an effective protection against environmental degradation. ${ }^{35}$

What is not mentioned in the above passages are the millions of farmers who are affected by the crackdown on beef sales and consumption. Droughts or unseasonal rains can create bad harvests which put a strain on farmers in feeding their livestock. For years, they have been able to sell off the financial burden of cattle to Muslim butchers, and then buy new stock when they recover their earnings. The ban, which has been in place but until recently, was not strictly enforced but now puts a strain on farmers who are unable to buy seed or provide for their families; this also has forced beef prices to drop sharply.

Yet, ongoing violence against both Dalits and Muslims in the name of cow protection highlights a problem with prioritizing cows over all other lives. The language has been cautious: "Lynching a person merely on suspicion is absolutely wrong," a BJP national executive stated in the Indian Express. ${ }^{36}$ The unspoken suggestion could be understood that one needed proof before lynching. This sentiment becomes more apparent as the author suggests that Muslims are impeding Modi's "national project" and are deliberately silent on the subject of jihadi attacks on Hindu citizens. This justification of violence is visible in other arenas as well.

Gau Rakshaks see this violence as their duty. "Today [Modi] is calling us thugs. But our work and night patrol will continue," one young man was reported of saying. Another stated "Either we die or they die. But we won't let anyone eat beef here." ${ }^{37}$ In another report, a young man says, "I am a cow patriot and want to free cows from the slavery of Muslim butchers. It's better we shed our blood to save the blood of cows." 38 The disregard for human

\footnotetext{
${ }^{35}$ Bharatiya Janata Party 1998.

${ }^{36}$ Vijay 2015.

${ }^{37}$ Gowen 2016.

${ }^{38}$ Jain and Lasseter 2016.
} 
life in favor of the life of a cow has little to do with religion and everything to do with a myopic fanaticism in which nationalism is the "religion" that dominates Indian media.

\section{CONCLUSION}

The sacred nature of the cow is tied to caste, notably Brahminic ideals of ritual and symbol, as well as the values of purity and exclusion. However, the oftmade argument that this hearkens back to a fundamental quality of Hinduism is a false claim. First, the Cow Protection Movement began in the late nineteenth century, and could be understood as an example of "sanskritization"- - that is, the presentation of upper-caste traditions as a pure, unadulterated Hinduism that is informed doctrinally. It has since then waxed and waned in popularity, only recently coming into fashion again when Modi promised the banning of all cow slaughter as part of his election platform. Second, there are many who argue that cow protection is based on Jain beliefs of purity, not the ethics of the Vedas (which frequently featured animal sacrifice). The Jains have very strict regulations around purity, not only abstaining from meat, but also from many other foods. Furthermore, it has been argued that Brahmins took up this extreme idea of food purity to further define themselves against both Muslims and Buddhists.

While caste purity has long informed the discussion around meat consumption, the issues of cow protection-and the resulting violence against Muslims and Dalits who are even suspected of eating beef - are most certainly tied to Hindu nationalism and how certain religious/cultural traditions are argued to be most "authentic" or "pure." The illusion of cultural homogeneity is ever-present in Hindu nationalist discourses. Sudipta Kaviraj has observed that nationalism relies on a false consciousness: "If there is any field about which nationalist thought establishes plausible but misleading narratives, it is about the society it tries to bring under its political control and its historical self-representation." ${ }^{39}$ The control over the presentation of history, therefore, is the control over cultural presentation, and that control is predicated upon the assumption that history is stable, closed, contiguous, and-perhaps most importantly - that it manages to remain undistorted when viewed through the lens of the present. The present valorization and sacralization of the cow, while undoubtedly an important contributor of staple foods and fuel, has less to do with scripture and more to do with political Hinduism. As Muslims continue to be viewed as a threat to Hindu hegemony, and Dalits continue to be dehumanized, the issue of cow protection serves to legitimate violence against those who destabilize the ideal of a Hindu nation.

\footnotetext{
${ }^{39}$ Kaviraj 2010, 87.
} 


\section{BIBLIOGRAPHY}

Appadurai, Arjun. 2006. Fear of Small Numbers. Duke University Press. doi: https://doi.org/10.1215/9780822387541

Arendt, Hannah. 1973. The Origins of Totalitarianism. New York: Houghton Mifflin Harcourt.

Bharatiya Gau Raksha Dal. 2014. “Our Top Mission . ..” 9 April, http://bgrd.in/ what-we-do/. Accessed September 2016

Bharatiya Gau Raksha Dal. 2016. "Heinous Act of Cow Slaughtering." 6 July, http:// bgrd.in/heinous-act-of-cow-slaughtering/. Accessed September 2016

Bharatiya Janata Party. 1998. “1998 Election Manifesto” http://www.bjp.org/en/ documents/manifesto/bjp-election-manifesto-1998/chapter-6. Accessed September 2016.

Bharatiya Janata Party. 2014. “2014 Election Manifesto” http://www.bjp.org/images/ pdf_2014/full_manifesto_english_07.04.2014.pdf. Accessed September 2016.

Dirks, Nicholas, 2001. Castes of Mind: Colonialism and the Making of Modern India. Princeton University Press.

Doniger, Wendy, 1991. The Laws of Manu. Translated by Wendy Doniger. New York City: Penguin Books.

Doniger, Wendy, 1981. The Rig Veda: An Anthology. Translated by Wendy Doniger. New York City: Penguin Books.

Nair, Rupam Jain, and Frank Jack Daniel. 2015. "Battling for India's Soul, State by State." The Week, 12 October, http://www.reuters.com/article/us-indiarss-specialreport-idUSKCNOS700A20151013. Last accessed February 2017.

Freitag, Sandria. 1980. "Sacred Symbol as Mobilizing Ideology: The North Indian Search for a 'Hindu' Community.' Comparative Studies in Society and History 22(4): 597-625. doi: https://doi.org/10.1017/S0010417500009567

Gandhi, Mahatma. 1940. Harijan. 15 September.

Gandhi, Mahatma. 2009. India of My Dreams. New Delhi: Rajpal and Sons.

Gowen, Annie. 2016. “India's Prime Minister Breaks Silence on Hindu Cow Protectors, Calling Them 'Fake.'" The Washington Post, 8 August, https:// www.washingtonpost.com/news/worldviews/wp/2016/08/08/tide-turnsagainst-indias-cow-protection-vigilante-squads/. Last accessed October 2016.

Henry, Nikhila. 2015. "OU Students Hold Preview of Beef Festival." The Hindu, 9 December, http://www.thehindu.com/news/cities/Hyderabad/ou-studentshold-preview-of-beef-festival/article7963453.ece. Last accessed November 2016.

Jaffrelot, Christophe. 2016. "Hindutva's Purification Drive." Indian Express, 13 October, http://indianexpress.com/article/opinion/columns/hindutvaspurification-drive-muslims-india-islam-caste-system-3079478/. Last accessed November 2016. 
Jain, Rupam, and Tom Lasseter. 2016. "Holy Cows and Hindu Crusaders Cloud Modi's Indian Reform Drive." Reuters, 12 August, http://www.reuters.com/ article/us-india-modi-cows-insight-idUSKCN10J2J1. Last accessed October 2016.

Jayaram, N. 2011. "Caste, Corporate Disabilities and Compensatory Discrimination in India: Colonial Legacy and Post-colonial Paradox." In Colonialism and Welfare: Social Policy and the British Imperial Legacy. Edited by James Midgley and David Piachaud. Cheltanham, UK: Edward Elgar Publishing, 85-99. doi: https://doi.org/10.4337/9781849808491.00013

Jha, Dwijendra Narayan. 2002. The Myth of the Holy Cow. London: Verso.

Kaviraj, Sudipta. 2010. The Imaginary Institution of India: Politics and Ideas. Columbia University Press. doi: https://doi.org/10.7312/kavi15222

Lawler, Andrew. 2004. “The Indus Script: Write or Wrong?” Science 306: 2026-2029. doi: https://doi.org/10.1126/science.306.5704.2026

Olivelle, Patrick. 1996. Upanisads. Oxford University Publishing.

Prabhu, Maya. 2016. "India's Dalit Cattle-skinners Share Stories of Abuse." Al Jazeera, 25 August, http://www.aljazeera.com/indepth/features/2016/08/ india-dalit-cattle-skinners-share-stories-abuse-160816122203107.html. Last accessed August 2016.

Rao, Anupama. 2009. The Caste Question. University of California Press.

Savarkar, V. D. 2005 [1923]. Hindutva: Who Is a Hindu? New Delhi: Hindi Sahitya Sadan.

Vijay, Tarun. 2015. "Death in Dadri." Indian Express, 2 October, http://indianexpress. com/article/opinion/columns/death-in-dadri/. Last accessed August 2016.

Zeiler, Xenia. 2013. "Benevolent Bulls and Baleful Buffalos: Male Bovines versus the 'Holy Cow' in Hinduism." In Animals as Religious Subjects: Transdisciplinary Perspectives. Edited by Celia Deane-Drummond, Rebecca Artinian-Kaiser, David L. Clough. Bloomsbury Press, 125-148. 